\title{
Integrated digital platforms for development of transport and logistics services
}

\author{
Dmitriev Aleksander Viktorovich \\ Associate Professor at the Department of Logistics and \\ Supply Chain Management \\ St. Petersburg State University of Economics \\ Saint-Petersburg, Russia \\ poliskasko@bk.ru
}

\author{
Plastunyak Irina Aleksandrovna \\ Associate Professor of the Department of \\ Customs \\ St. Petersburg State University of Economics \\ Saint-Petersburg, Russia \\ plastounjak@mail.ru
}

\begin{abstract}
The article discusses the development of transport and logistics services based on integrated digital platforms, analyzes the Russian economy and its transport and logistics sector digitalization level, explores the features of transport and logistics systems digital transformation, substantiates the digital platform concept for the development of transport and logistics services, suggests a digital transport logistics platforms typology and the principles of their construction, analyzes the global digital platforms application experiences, the processes of structural transformation and network convergence of regional information spaces are considered, the use of e-logistics model is substantiated as a key direction for improving cargo delivery processes from shipper to consignee, advantages and disadvantages are explored, criteria for successful partnership are being developed in terms of horizontal and vertical integration of transport and logistics organizations, identified appropriate use areas of digital logistics tools
\end{abstract}

Key words- digitalization, visibility, transport and logistics service, digital platforms, electronic logistics, network convergence, vertical integration, coordinated logistics, blockchain

\section{INTRODUCTION}

In modern economic conditions, the digitalization of the various Russian economy sectors, in particular, the transport and logistics sector, is receiving increased attention. This testifies to the intensification in recent years of measures for the Russian Federation strategic development related to the implementation of state policy, regulated by Decree No.

1632-p of July 28, 2017 "On Approval of the Russian Federation Digital Economy Program" and Resolution of the Russian Federation Government of August 28, 2017

№1030 “On the management system of the program "Russian Federation Digital Economy" implementation".

Representatives of academia, government agencies, and the business community are involved in developing ways to increase the efficiency of digital transformation. At the same time, following the program "Russian Federation Digital Economy", efforts should be aimed first of all at creating conditions for the development of a knowledge society, improving well-being and living standards, availability, quality of goods and services produced in the digital economy $[1,2]$.

However, it should be recognized that so far in the context of the digitalization of the Russia economy and its transport and logistics sector there are some debatable issues and unresolved problems. In particular, experts somewhat differ in their assessment of the component of digitalization in the overall structure of Russia's GDP. Also, it requires a deeper study of the methodology and mechanisms for digitalization, as well as a platform concept for the transport and logistics services suppliers and consumers integration.

\section{EVALUATION OF THE RUSSIAN ECONOMY DIGITALIZATION LEVEL}

According to the Boston Consulting Group, there has been a generally positive, albeit restrained, dynamic of the digital economy share in the overall Russian Federation's GDP structure in recent years. In 2018, growth was $24 \%$, to a value of 2.6 trillion rub. From 2009 to 2018 , the digital economy of the Russian Federation grew by about 2.5 times (258\%) [3].

As reported by McKinsey expert agency, the rate of digitalization in 2017 was equal to $3.9 \%$, while the lag of the digital economy's share in the Russian Federation GDP from the level of developed countries was stated [4].

Nevertheless, according to the forecasts of the McKinsey agency, it is planned to increase the volume of the digital economy by 3 times in 2025 by optimizing production and logistics operations based on monitoring production lines in real-time, optimizing logistics routes and determining the order of cargo shipments priority, increasing equipment productivity, reducing resource consumption and production losses, improving the efficiency of the labor market, R \& D, developing innovative products and other directions.

According to the Internet Development Institute on the specified indicator in 2018, Russia ranked 16th among the countries of the "group of twenty" (G20) (tab. 1, fig. 1) [5, p. $3]$.

TABLE I. SHARE OF THE DIGITAL ECONOMY IN G20 COUNTRIES GDP, \%

\begin{tabular}{|l|l|c|c|c|}
\hline \multicolumn{1}{|c|}{ № } & \multicolumn{1}{|c|}{ Country } & $\mathbf{2 0 1 0}$ & $\mathbf{2 0 1 8}$ & Growth, \% \\
\hline 1. & United Kingdom & 8.9 & 12.4 & $39.33 \%$ \\
\hline 2. & South Korea & 7.9 & 8.0 & $1.27 \%$ \\
\hline 3. & China & 5.5 & 6.9 & $25.45 \%$ \\
\hline 4. & European Union & 3.8 & 5.7 & $50.00 \%$ \\
\hline 5. & Japan & 4.7 & 5.6 & $19.15 \%$ \\
\hline 6. & India & 4.1 & 5.6 & $36.59 \%$ \\
\hline 7. & USA & 4.7 & 5.4 & $14.89 \%$ \\
\hline 8. & Mexico & 2.5 & 4.2 & $68.00 \%$ \\
\hline 9. & Germany & 3.0 & 4.0 & $33.33 \%$ \\
\hline 10. & Saudi Arabia & 2.2 & 3.8 & $72.73 \%$ \\
\hline 11. & Australia & 3.4 & 3.7 & $8.82 \%$ \\
\hline 12. & Canada & 3.0 & 3.6 & $20.00 \%$ \\
\hline 13. & Italy & 2.1 & 3.5 & $66.67 \%$ \\
\hline 14. & France & 2.9 & 3.4 & $17.24 \%$ \\
\hline 15. & Argentina & 2.0 & 3.3 & $65.00 \%$ \\
\hline
\end{tabular}




\begin{tabular}{|l|l|c|c|c|}
\hline 16. & Russia & 1.9 & 2.8 & $47.37 \%$ \\
\hline 17. & Brazil & 2.2 & 2.5 & $13.64 \%$ \\
\hline 18. & South Africa & 1.9 & 2.5 & $31.58 \%$ \\
\hline 19. & Turkey & 1.6 & 2.3 & $43.75 \%$ \\
\hline 20. & Indonesia & 1.3 & 1.5 & $15.38 \%$ \\
\hline
\end{tabular}

The share of the digital economy in the GDP of developed countries from 2010 to 2018 increased from $4.3 \%$ to $5.5 \%$, and in the GDP of developing countries from $3.6 \%$ to $4.9 \%$. In the $\mathrm{G} 20$ countries, this figure rose over five years from $4.1 \%$ to $5.3 \%$. United Kingdom is the world leader in the share of the digital economy in GDP $-12.4 \%$.

The gap between United Kingdom and the nearest rival is quite large and amounts to over $8 \%$. In this rating, Russia is on the 15 th place with indicators of a $2.8 \%$ digitalization rate. According to a study by analysts of International Data Corporation, published in 2018, total global costs of digital transformation technologies will grow by $16.8 \%$ annually and reach $\$ 2.1$ trillion by 2019 .

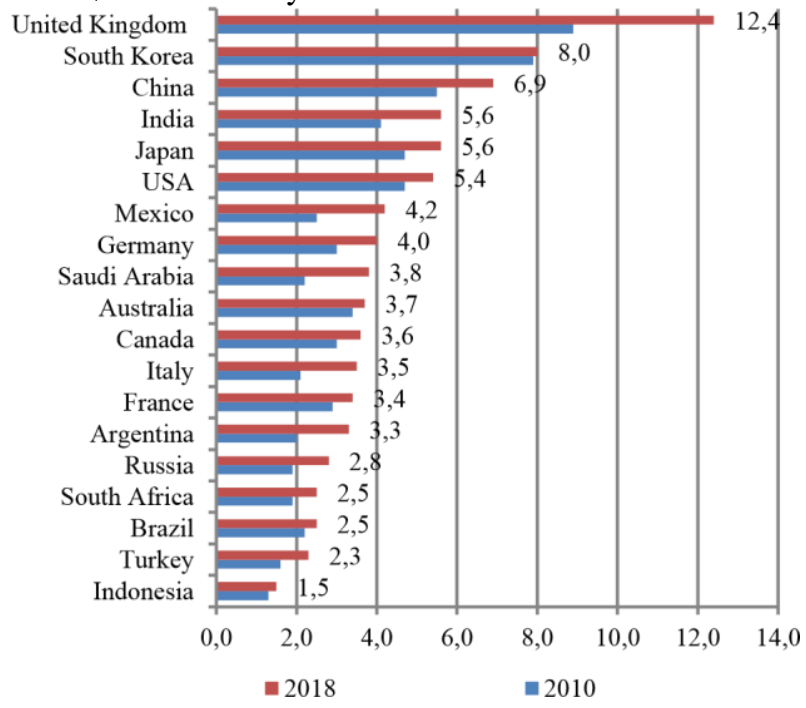

Fig. 1. The share of the digital economy in the GDP of countries G20, $\%$

According to forecasts of the consulting company Accenture, the use of digital technologies should add $\$ 1.36$ trillion in 2020 , or $2.3 \%$ of GDP in the total GDP of the world's leading economies. Due to the digital economy, the GDP of developed countries will grow by $1.8 \%$, and the GDP of developing countries - by $3.4 \%$ [6, p. 25]. BCG predicts the digital economy could reach $\$ 16$ trillion by 2035 .

As reported by the Russian Association of Electronic Communications (RAEC) and the Higher School of Economics (HSE) research, in 2018 the share of the digital economy in the Russian Federation's GDP grew 2.5 times from $2.1 \%$ to $5.1 \%$. [7] However, this indicator takes into account the mobile segment of the digital economy.

The study notes that the market units of the digital economy sector have a different share in the formation and development of the digital ecosystem in Russia: the size of the communications infrastructure market is estimated at 1.8 trillion rub. (43.6\%), e-commerce - 2 trillion rub. (48.4\%), advertising - 250 billion rub. $(6 \%)$, big data -3 billion rub. $(0.07 \%)$, digital content -75 billion rub $(1.8 \%)$.
The following growth drivers and structural components of the digital economy can be identified:

- mobile technologies;

- sharing economy;

- finance and trade;

- marketing and advertising;

- cybersecurity;

- media and entertainment;

- private and public investments in digitalization;

- export of information and communication technologies;

- and other areas.

According to Titov B.Yu., an expert of the Stolypin Institute for Growth Economics, at the present time the development of the digital economy in Russia lags behind the leading countries because there is an imbalance between the private initiatives in this area and the digitalization of the state, including the creation of new fiscal information systems [8].

Currently, information and communications technology sector in Russia consists of a small number of subjects. In 2018, there were only 0.8 enterprises per 1000 people, while in developed countries this figure was on average 2.7, which is 3 times more. In Russia, the number of people employed in the information and communication technology sector is 8.4 per 1000 employees. Russia is almost two times behind the leading countries, where the average index is 16 workers.

According to HSE, the Russian sector of the digital economy in terms of value added is structurally formed by more than one-third due to the activities of companies involved in telecommunication technologies, primarily the provision of communication services, including mobile, as well as Internet access. However, it should be recognized that from 2010 to 2018 , the share of telecommunications decreased from $50 \%$ to $38 \%$, and the information technology and services sector, on the contrary, shows a steady increase from $16 \%$ to $33 \%$. Doubling the share of the IT sector is associated primarily with data processing. At the same time, the industry of telecommunications equipment, in particular the production of components, online cash registers, state information and navigation systems (PLATON, GLONASS), which had previously maintained a fairly high share, has recently demonstrated a steady decline of $9 \%$ in 2018 compared to 2017 year. Negative dynamics is related to the performance of organizations engaged in the production of technical storage media (90\% compared to 2017), consumer electronics (87\%) and communication equipment (82\%) [9].

Thus, a significant increase in the level of penetration of digital technologies in various sectors of the real economy is confirmed by increasing investments in high-tech sectors. This makes it necessary to find new strategic directions for the innovative development of transport and logistics systems in the direction of digitalization. 


\section{DIGITAL TRANSFORMATION OF TRANSPORT AND LOGISTICS SYSTEMS}

In today's economic environment, in order to ensure the flexibility of supply chains, many companies transfer part of their business processes to outsourcing, which often leads to loss of control and the ability to make the performance of various logistic operations visible. The introduction of modern digital technologies through the visibility of supply chains may be a solution to this problem, including integrated transport and logistics systems visibility at all goods delivery stages from manufacturers to end users.

However, despite the fact that global commodity distribution networks are being formed and developed based on the active use of logistics methods and principles in building transportation systems and developing cargo delivery technologies, the widespread use of various logistic solutions is hampered by the insufficient level of transport logistics digitalization, which affects the target indicators of transportation processes and the overall economic efficiency of product distribution. One of the necessary conditions for the functioning of modern transport and logistics systems is the widespread use of modern digital technologies and logistics information systems, through which it is possible to manage orders, plan, organize, monitor and control the entire procedure for delivering goods. The information flow in this case will be not only anticipatory, but also determining in relation to the delivery process.

In addition, in their logistics practice, enterprises need to make extensive use of various electronic data interchange systems in order to increase their competitiveness in the market of freight forwarding services. In particular, intermodal transport and logistics systems achieve high performance by introducing new forms of information and communication interaction between the various links of the transport and logistics chain. And one of the key criteria for the effectiveness of such systems is the level of their business processes digitalization.

The work [10] emphasizes that the world leaders in transport and logistics services and supply chain management place particular emphasis on introducing digital technologies in their supply chains, such as RFID, Mobile app, Big Data, Cloud Services, IoT, BlockChain, 3DPrinting, etc.

The development trends of digital technologies, of course, have a significant impact on the construction of integrated logistics systems, the configuration of distribution channels, distribution networks and warehousing services. New digital information technologies are forcing more and more companies to use these technologies as factors to increase efficiency and reduce production and maintenance costs. The demand for the introduction of new methods and technologies increases as innovation attracts new customers. This gives enterprises an additional competitive advantage [11].

Logistics providers act as organizers of interactions between all links of the transport chain in the process of transport and logistics services and determine not only the commercial-legal, organizational-technological and financialeconomic regime, but also an electronic platform for interaction between the subjects of the specified system.

\section{DIGITAL PLATFORM CONCEPT OF TRANSPORT AND LOGISTICS SERVICE DEVELOPMENT}

Integrated digital logistic platform is a virtual information hardware and software environment for transport and logistics operations and services [12]. The platform is a set of algorithmic and economically viable relationships between a significant number of independent participants in transport and logistics systems (or supply chains). These relationships are carried out within the framework of a unified integrated information environment leading to a decrease (optimization / minimization) of total logistics costs through the use of digital information and communication technologies for working with an array of logistics data with any level of structure (supply and demand parameters for logistics services, information about objects, subjects, processes in logistics systems, etc).

The principles of building logistics platforms include:

- Algorithm of platform participants interaction.

- Mutual collaboration benefit for platform participants («win-to-win» principle).

- Significance of number of the participants using the platform for interaction.

- The presence of a unified information environment and the corresponding information technology infrastructure in which the interaction of participants is carried out.

- The presence of the reducing transaction costs effect in the interaction of various platform participants compared with the same interaction without the platform.

Based on the developments of the Rostelecom Informational Competence Center in the field of information infrastructure, it is possible to present a typology of transport logistics digital platforms based on the following characteristics: subject composition, functional specialization, information processing methods, and the result of activities (tab. 2).

There are different types of digital platforms in transport logistics:

1) Instrumental digital platforms consist of software and hardware systems (products, standards, libraries, interfaces, tools) designed to create applied software and hardware solutions in the field of transport logistics.

2) Infrastructure digital platforms are ecosystems of information technology market participants, the purpose of which is to accelerate their entry into the market and provide automation solutions to consumers in economic sectors. It uses end-to-end digital technologies for working with data and access to data sources. This is implemented in the infrastructure of this ecosystem.

The global experience of transition to platform technologies involves competition between leading transport and logistics companies in the speed of acquiring digital startups and launching integrated digital transport and logistics platforms. 
DHL Freight introduced the CILLOX digital cargo platform, which is positioned as a virtual market for enterprises-consumers of transport services and is designed to optimize rolling stock loading in three main ways: full truck load (FTL), partial truck load (PTL), combined transportation (less than one truck load or LTL), as well as searching for a supplier of transport and logistics services in accordance with the needs of the cargo owner. This service allows shippers to provide end-to-end control and visibility of transport and logistics processes within a single platform, and transport providers receive guarantees of speed and efficiency of payment for services rendered and document flow optimization from the point of view of formation of commodity-transport documentation, including bills of lading, invoices, etc. [13]

\section{TABLE II. TYPOLOGY OF TRANSPORT LOGISTICS} DIGITAL PLATFORMS

\begin{tabular}{|c|c|c|c|}
\hline & $\begin{array}{c}\text { Instrumental } \\
\text { (functional and } \\
\text { technological) } \\
\text { platforms }\end{array}$ & $\begin{array}{l}\text { Infrastructure } \\
\text { platforms }\end{array}$ & Applied platforms \\
\hline Subjects & $\begin{array}{l}\text { Platform solution } \\
\text { developers }\end{array}$ & $\begin{array}{l}\text { Customers } \\
\text { (government } \\
\text { agencies); executors: } \\
\text { information providers, } \\
\text { platform operator, } \\
\text { platform developer, } \\
\text { developers; } \\
\text { information service } \\
\text { consumers }\end{array}$ & $\begin{array}{l}\text { Participants in } \\
\text { transport and logistics } \\
\text { systems: suppliers and } \\
\text { consumers of transport } \\
\text { and logistics services } \\
\text { and resources, } \\
\text { platform operators, } \\
\text { regulators }\end{array}$ \\
\hline $\begin{array}{l}\text { Functional } \\
\text { specialization }\end{array}$ & $\begin{array}{l}\text { Development and } \\
\text { implementation } \\
\text { of software and } \\
\text { hardware } \\
\text { platform } \\
\text { solutions }\end{array}$ & $\begin{array}{l}\text { Provision of } \\
\text { information and } \\
\text { communication } \\
\text { services and } \\
\text { information for } \\
\text { decision making }\end{array}$ & $\begin{array}{l}\text { Receipt and exchange } \\
\text { of additional economic } \\
\text { value in the transport } \\
\text { and logistics market }\end{array}$ \\
\hline $\begin{array}{l}\text { Information } \\
\text { processing } \\
\text { technique }\end{array}$ & $\begin{array}{l}\text { Technological } \\
\text { processing of } \\
\text { information }\end{array}$ & $\begin{array}{l}\text { Development of } \\
\text { information for } \\
\text { decision-making at the } \\
\text { level of the transport } \\
\text { and logistics system } \\
\text { subject }\end{array}$ & $\begin{array}{l}\text { Processing and } \\
\text { analysis of information } \\
\text { on the conclusion and } \\
\text { execution of } \\
\text { transactions between } \\
\text { several subjects of the } \\
\text { transport and logistics } \\
\text { market, total } \\
\text { transactional detail and } \\
\text { visibility }\end{array}$ \\
\hline $\begin{array}{l}\text { Activity } \\
\text { result }\end{array}$ & \begin{tabular}{|l|} 
Instrumental \\
software and \\
hardware for \\
information \\
processing for \\
three-dimensional \\
logistic design
\end{tabular} & $\begin{array}{l}\text { Information and } \\
\text { communication } \\
\text { service and the result } \\
\text { of its work - the } \\
\text { information necessary } \\
\text { for decision-making in } \\
\text { the implementation of } \\
\text { transport and logistics } \\
\text { activities }\end{array}$ & $\begin{array}{l}\text { A transaction that fixes } \\
\text { the exchange of goods/ } \\
\text { services between } \\
\text { participants in a given } \\
\text { market }\end{array}$ \\
\hline Examples & \begin{tabular}{|l|} 
WebGL, W2MO, \\
OpenGL, iOS, \\
API DirectX, \\
Unity 3D, \\
VRML/X3D, \\
Java, Android, \\
TensorFlow, \\
Microsoft \\
Azure, Amazon \\
web services, \\
1C, \\
Bitrix, SAP \\
HANA
\end{tabular} & $\begin{array}{l}\text { The project of the } \\
\text { digital platform of the } \\
\text { transport complex of } \\
\text { the Russian } \\
\text { Federation, the } \\
\text { Transport regulation } \\
\text { system, the Unified } \\
\text { State Information } \\
\text { System for Transport } \\
\text { Security, the State } \\
\text { Automated } \\
\text { Information System } \\
\text { "ERA-GLONASS" }\end{array}$ & $\begin{array}{l}\text { UBER, YandexTaxi, } \\
\text { Wheely, AeroTaxi, } \\
\text { BlaBlaCar, } \\
\text { CarSharing, Aviasales, } \\
\text { Charging system } \\
\text { «Platon», Cainiao, } \\
\text { GroozGo, ATI, } \\
\text { iCanDeliver, Axelot } \\
\text { TMS }\end{array}$ \\
\hline
\end{tabular}

In Holland, the digital cargo platform Saloodo is launched, uniting the shippers into a single digital cargo market for both domestic transportation in the Netherlands itself and for delivery of goods in international traffic from the Netherlands to other countries of the European Union and back. This platform currently brings together more than 10,000 shippers, over 6,000 forwarders and about 25,000 units of transport.

Considering the development of transport and logistics services based on the use of integrated digital platforms, it should be noted that these platforms are the informational core of logistic systems of the network type and provide interaction between other subsystems at various management levels, including macro and mega levels.

In [13], the processes of structural transformation and network convergence of regional information spaces are considered. The importance of deploying an integrated digital platform within a separate state, and later, given the trend of erasing information borders between countries, and international integrated platforms is noted. In this regard, mention is made of the study of the Center for Strategic Research "State as a Platform" [14], in which citizens and businesses are considered as the main recipients of public services in electronic form, and all users operate with common databases with different levels of access. At the same time, additional synergistic effect for business is achieved by applying advanced methods of network interaction, management of network behavior, as well as "through hypercompetitive creative neuromarketing, management, logistics, etc." [14, c. 1198].

Digital transformation in logistics determines the appearance of its new forms and types, such as digital logistics or electronic logistics (e-logistics). These types of logistics use modern information technologies and intelligent transportation and storage management systems, which can now be considered as a key direction for improving the delivery of goods from the shipper to the consignee, subject to all the principles and methods of logistics.

In [15], e-logistics was proved to be a key factor in the growth of a country's economy, and the most important indicators determining customer satisfaction with logistics services are minimum distribution and transit time, efficient payment methods and the use of information technology.

An important factor in the development of integrated digital platforms should be considered the fact that these platforms provide various forms and types of integration between the subjects of transport and logistics systems, including between suppliers and consumers of transport and logistics services.

The work [16] is devoted to advantages and disadvantages, as well as comparison of horizontal and vertical integration of organizations. Vertical integration is considered as integration between the transport intermediary and the shipper in order to obtain mutual benefits and reduce overall logistics costs, which is sufficient for large companies. Whereas small firms could take advantage of horizontal integration, share the "economies of scale", offer additional services to increase the efficiency of individual logistics operations. To evaluate 
potential partners, it is proposed to use ANP (Analytic Network Process) modeling based on four criteria (fig. 2).

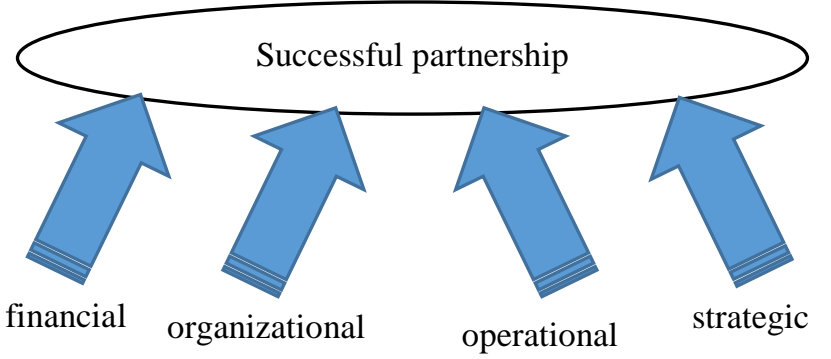

Fig. 2 - Criteria for a successful vertical partnership [16, p. 442- 445]

On the one hand, it is necessary to agree with Freeman C., who understands by innovation in his work [17] all products that are new to an individual organization, but at the level of sectoral integration, this provision should be expanded and take into account that the innovative approach implies a complete change ideologies. In addition, the digital logistics platform contributes to increasing the manageability of communications and coordination of interaction between the supply chain.

The paper [18] addresses the issues of coordinated construction logistics based on three models: companybased, project-based and system-based. The author concludes that it is necessary to move from gradual to systemic innovations and adhere to a broader consideration of the supply chain. Despite the fact that this problem is considered by the author taking into account the specifics of the construction sector, it can be argued that any innovative changes require similar tools.

The mutual influence of operating activities, integration processes and logistics are considered in [20]. At the same time, the authors note that the most significant is the exchange of information to improve the efficiency of the entire supply chain.

There are trends in the complexity of the supply chain, which requires changes in management technology. Blockchain technology is changing relationships in the supply chain between the parties. IT technologies allow "to create, improve and maintain relations between a large number of participants in the supply chain" [19, p. 51] and quite often considered as a key factor in reducing total logistics costs $[21$, 22].

\section{CONCLUSION}

Thus, digital transformation, due to the high level of progress in microelectronics and telecommunications, is an objective process and has a great influence on the activities of companies in the field of transport and logistics services and supply chain management.

The development of transport and logistics services based on integrated digital platforms and the use of digital logistics tools, such as blockchain, increase the reliability and stability of the supply chains and shorten the delivery time for goods, because it ensures the relevance and accuracy of cargo information that is accessible to all interested parties, allows predictive development solutions of potential problems in the work of transport and logistics systems and to obtain a significant economic effect.

\section{REFERENCES}

[1] Decree of the Russian Federation Government of August 28, 2017 No. 1030 "On the management system for the implementation of the Russian Federation Digital Economy program" URL: http://government.ru/docs/29003/

[2] Order of the Russian Federation Government of July 28, 2017 No. 1632-p "On approval of the program "Russian Federation Digital Economy" URL: http://static.government.ru/media/files/ 9gFM4FHj4PsB79I5v7yLVuPgu4bvR7M0.pdf

[3] Russia online: four priorities for a breakthrough in the digital economy (2019) URL: http://image-src.bcg.com/Images/RussiaOnline_tcm27178074.pdf

[4] Digital Russia: a new reality (2019) URL: $\quad$ http://www.tadviser.ru/images/c/c2/Digital-Russiareport.pdf

[5] Digital economy: a course in 2017. / Rudykh E.S. Internet Development Institute URL: http://files.runetid.com/2016/itogi2016/presentations/14dec.itogi2016-1-12-30-1330-rydih.pdf

[6] Digitalization of transport logistics (2018) / A.V. Dmitriev. - SPb. : St. Petersburg State University of Economics, 2018. - 161 p.

[7] Runet Economics - Ecosystem of the Russian Digital Economy (2019) URL: http:/цифроваяэкономика.рф/

[8] Russia: From Digitalization to Digital Economy (2018) URL: http://stolypin.institute/wp-content/uploads/2018/09/issledovanie_ tsifrovaya-ekonomika-14-09-18-1.pdf

[9] Information and communications sector in Russia URL: https://issek.hse.ru/news/227732702.html

[10] Sergeev V.I., Dybskaya V.V. Global trends in supply chain management development (2018) // Logistics and supply chain management. No 2. pp. 3-14.

[11] Grigoriev, M.N., Maximtsev, IA, Uvarov, S.A. Digital platforms as a resource for improving the competitiveness of supply chains (2018) // News of St. Petersburg State University of Economics. 2018. No 2 (110). pp. 7-11.

[12] DHL introduces digital freight platform (2017) URL: https://postandparcel.info/76061/news/dhl-introducesdigital-freightplatform/

[13] Dyatlov S.A., Lobanov O.S., Zhou W.B. The Management of Regional Information Space in the Conditions of Digital Economy // Economy of Region, 2018, vol. 14, no 4, pp. 1194 - 1206.

[14] Petrov M. State as a platform (2018). (Cyber) state for the digital economy. Digital Transformation / M. Petrov et al. // Center for Strategic Research. - Moscow URL: https://www.csr.ru/wpcontent/uploads/2018/05/gosudarstvo-kakplatforma_internet.pdf.

[15] Imran, M., Abdul Hamid, Aziz A.B., Waseem-Ul-Hameedb. The contributing factors towards e-logistic customer satisfaction: A mediating role of information technology (2019) // Uncertain Supply Chain Management, 2019, vol. 7, no 1, pp. 36 - 72.

[16] Abidi H., Dullaert W., De Leeuw S., Lysko D., Klumpp M. Strategic partner evaluation criteria for logistics service provider networks // International Journal of Logistics Management, 2019, vol. 30, no 2, pp. $438-466$.

[17] Freeman C. Economics of Industrial Innovation / C. Freeman. London: Routledge, 1997. - 484 p.

[18] Hedborg Bengtsson S. Coordinated construction logistics: an innovation perspective / S. Hedborg Bengtsson// Construction Management and Economics, 2019, vol. 37, no 5, pp. 294-307.

[19] Min S., Zacharia Z.G., Smith C.D. Defining Supply Chain Management: In the Past, Present, and Future // Journal of Business Logistics, March 2019, vol. 40, no 1, pp. 44-55.

[20] Naway F.A., Rahmat A. The mediating role of technology and logistic integration in the relationship between supply chain capability and supply chain operational performance // Uncertain Supply Chain Management, 2019, vol. 7, no 3, pp. 553-566. 
[21] Gnimpieba Z. D.R., Nait-Sidi-Moh A., Durand D., Fortin J. Using Internet of Things technologies for a collaborative supply chain: Application to tracking of pallets and containers // Procedia Computer Science, 2015, vol. 56, no 1, pp. 550-557

[22] Chen W., Feng G., Zhang, C., Liu P., Ren W., Cao N., Ding J. Development and application of big data platform for garlic industry chain // Computers, Materials and Continua, 2019, vol. 58, no. 1, pp. $229-248$ 